\title{
The Solow Residual as a Black Box: Attempts at Integrating Business Cycle and Growth Theories
}

\author{
Tiago Mata and Francisco Louçã
}

The intersection between growth and business cycle theory remains a controversial subject in economics. The question posed by this article is, What role did Robert Solow's "Technical Change and the Aggregate Production Function" (1957) play in recent attempts to integrate business cycle and growth theory? We argue that the "Solow residual" was a resource given to multiple uses, at times rhetorical and symbolic, at times instrumental for theory development, at others a social artifact.

The Solow residual is herein conceived as an object. We examine the history of fluctuations in growth theory in a narrative of model building, of the addition and subtraction of elements to models. Our views are informed by the concept of the black box associated with the work of Bruno Latour and colleagues (Latour 1987; Latour and Woolgar 1979). Their notion is that theoretical and experimental artifacts can attain a status of consensual acceptance that exempts them from close examination. It is in this sense that they are said to be "closed."

Our use of the term black box is felicitous for another reason. The term has an established lineage in controversies over the role of innova-

We are indebted to the participants at the 2008 HOPE conference for their insightful commentary on this article. Lionello Punzo, Marcel Boumans, Nicholas Crafts, Michel De Vroey, and David Warsh were generous in offering suggestions and corrections both during and after the meetings. We also thank two anonymous referees who gave a careful and thoughtful reading of this article. Tiago Mata has benefited for the writing of this article from a postdoctoral fellowship (SFRH/BPD/30403/2006) from the Fundação para a Ciência e Tecnologia, Portugal.

1. For a test of Latour's semiotics, see Yuval Yonay's (1994) study of institutional economics.

History of Political Economy 41 (annual suppl.) DOI 10.1215/00182702-2009-031

Copyright 2009 by Duke University Press 
tion in economic growth. We agree with Nathan Rosenberg's (1982) judgment that "economists have long treated technological phenomena as events transpiring inside a black box. ... [and] adhered rather strictly to a self-imposed ordinance not to inquire too seriously into what transpires inside that box." Our story, which begins in 1982, at the time of Rosenberg's book, suggests that the box, when opened, became a source of multiple puzzles. But before we consider the uses given to the object, we have to observe how neoclassical growth theory canonized the Solow residual.

\section{Solow's Residual and Growth's Black Box}

The influence of Solow's "Technical Change and the Aggregate Production Function" cannot be overemphasized. The piece followed closely the publication of Solow's (1956) celebrated growth model and was intended as a contribution to the literature on growth. ${ }^{2}$ Its startling conclusion was that "gross output per man hour doubled over the interval [1909-49], with $87 \frac{1}{2}$ per cent of the increase attributable to technical change and the remaining $12 \frac{1}{2}$ per cent to increased use of capital." Solow humbly acknowledged that the result lacked great depth or insight. He noted soon after that

in every-day speech, talk of technological change calls to mind primarily single discontinuous inventions, like the electric light or the automobile or the electronic computer.... But most of this flavor disappears in statistical aggregates.

Economists, who give the impression of having invented the idea of technological progress in the past 6 or 7 years, have something much more pedestrian in mind, . . "increase in output per unit of input." It is a statistical artifact. (Solow 1963, 37)

It was immediately understood that such a large proportion of growth left unaccounted for by the factors of production was a problematic result. Frank Hahn and R. C. Matthews $(1964,832)$, in their "monumental" 120-page survey of growth theory, noted that "those who used the 'residual' approach were well aware that the residual, as its name implies, is a catch-all and that in practice the task of research would be to break it up into its constituent components."

2. For a survey of what was in the 1950s and 1960s a vibrant field of econometric study, see Walters 1963. 
The field of growth accounting blossomed in the 1960s, particularly following the lead of Edward Denison (1962, 1979, 1985; Denison and Brookings Institution 1967, 1974). As Nicholas Crafts (this volume) establishes in his survey, the residual resisted the multiple accounting models. As Christopher Freeman $(1988,2)$ graphically put it: "The various 'growth accounting' exercises, even after allowing for an entire Kamasutra of variables, generally remain with a big unexplained 'residual' and fail to deal with the complementarities and interactions of these variables." Denison $(1967,283)$ was aware of the difficult interpretation of the residuals, which include "contributions of advances in the lag of average practice behind the best known but also the net effect of errors in the growth rates themselves, of errors in estimates of the contributions made by other sources of growth, and of omission of all sources not specifically estimated."

Alongside the accounting exercises, in theory development, Solow's contribution brought into focus the need to formalize "innovations" (Burmeister and Dobell 1970). Solow's own views on the multiple formulations of the aggregate production function leaned toward labor-augmenting technological progress and capital "vintages" with differing productivities. Yet, despite the insight afforded by these developments, the dynamic rested in the technology component represented by the residual, "to change the rate of growth of real output per head you have to change the rate of technological progress." Significantly, such improvements stood largely outside the model's explanatory purview, as follows from the statement that policy measures "involve considerations quite outside the model we have been discussing" (Solow 1970, 77).

The residual's resilience led to comfort in the belief that "innovation" was an indistinct and impenetrable stream whose source was in the domain of other branches of economics. The Solow residual was a statistical artifact, yet it seemed to decide on the division of labor between growth and other theoretical quarters. This occurred despite Solow's (1985) misgivings about sharply drawn divisions of labor or dogmatic acceptance of neoclassical theory. Solow's work had gained a life of its own in the research of other authors and was autonomous of his intentions or interpretations. ${ }^{3}$

3. Coupled with the subject of innovation was uncertainty. It was a difficulty that growth theory could not face and should hence ignore (Solow 1963, 15). Solow's deterministic standpoint remained unchanged, when two decades on, Solow wrote to Frank Hahn: "Regarding ... fluctuations, Schumpeterian innovations, and all that. I find myself driven to the uncomfortable view that probability is not the right way to handle such things as innovations or other real shocks. . . Last thing in the world I want to spend time on is axiomatizing Knightian uncertainty. Maybe some ad-hoc device to get away from simple-minded mean-value thinking. Maybe better to dodge the whole thing" (Solow 1984). 


\section{Shocks and Business Cycle's Black Box}

In separate quarters Robert Lucas and his coauthors were championing in the 1970s a new approach to macroeconomics. ${ }^{4}$ It was a model-building approach, where

a "theory" is not a collection of assertions about the behavior of the actual economy but rather an explicit set of instructions for building a parallel or analogue system - a mechanical, imitation economy. A "good" model, from this point of view, will not be exactly more "real" than a poor one, but will provide better imitations. (Lucas 1980, 697)

The early literature commenting on new classical macroeconomics has emphasized the rational expectations hypothesis (Kantor 1979; Laidler 1981; Tobin 1981; Begg 1982; Blaug 1980; Sheffrin 1983), ${ }^{5}$ but to Lucas the discriminating feature of his models was a new notion of equilibrium. Models were "constructed so as to predict how agents with stable tastes and technology will choose to respond to a new situation" (Lucas 1977, 12; emphasis in original). Lucas and Sargent (1979, 7) attributed earlier notions of equilibrium to a distant legacy of John Maynard Keynes and his General Theory, stating that "the term equilibrium was thought to refer to a system at rest," but "the meaning of the term equilibrium has changed so dramatically that a theorist of the 1930s would not recognize it. An economy following a multivariate stochastic process is now routinely described as being in equilibrium, by which is meant nothing more than that at each point in time" that markets clear and agents act in their own self-interest. ${ }^{6}$

Influential papers by Lucas $(1972,1975)$ embodied this program. Lucas's models describe a stationary process around a deterministic time trend representing a "natural rate of growth," whereas serially correlated variations of the levels of the economy motivated by exogenous random shocks create the cycles. The solution for the whole economy indicates the properties of the cyclical component, as agents confound variations

4. This work had its predecessors, most notably Milton Friedman. The terms of this monetarist ancestry are controversial; see Hoover 1988 for a review of that debate and Kim 1988 for an account of Austrian threads.

5. For a critical examination of rational expectations complex history, see Sent 1998.

6. Lucas's caricature of Keynes is not historically accurate. For Keynes equilibrium arose from the matching of individual plans of saving, hoarding, and investment. It is a rather more dynamic story than Lucas portrays. On the history of equilibrium notions in economics, see Weintraub 1991. Lucas (2004) has recently suggested that his background had a great deal more Keynesianism than he avowed in print in the 1970s. For a critical assessment of Lucas's education, see Louçã 2004. 
of relative and general price levels (Dore 1993, 68, 75). The economic intuition is that agents confound unanticipated monetary shocks, with no real effects, with shocks in relative prices, implying substitution effects. The exogenous shocks have no permanent influence on the behavior of the system.

The seminal and canonical paper on real business cycles is Finn Kydland and Edward C. Prescott's "Time to Build and Aggregate Fluctuations" (1982). ${ }^{7}$ The authors' stated purpose was to "integrate growth and business cycle theory," conceiving real shocks as their distinction from Lucas's business cycle models. As they later stated, "Economic activity in industrial market economies is characterized by sustained growth. Lucas defines business cycles as deviations of real GNP from trend. . . But Lucas does not define trend, so his definition of business cycle deviation is incomplete" (Kydland and Prescott 1990, 6). Kydland and Prescott's (1982) "time-to-build" production function was composed of a persistent and a transitory element, interpreted as a technological shock. ${ }^{8}$ Production was explicitly modeled with agents not only optimizing the investmentconsumption decision but also allocating time between employment and leisure. ${ }^{9}$

7. In a bibliometric study of the most-cited academic articles post-1970, Kydland and Prescott 1982 was ranked sixty-first, being cited 814 times (Kim, Morse, and Zingales 2006). In 1972, William Brock and Leonard Mirman published in the Journal of Economic Theory a paper presenting a basic model of growth of a single sector with stochastic impulses to the production function, and established the proof of ergodicity required for time series econometrics. Real business cycle theorists do not ignore this work. But references are sparse, centered on the peculiar contribution of the ergodicity proof and not recognizing the core idea that was present in the 1972 paper and that anticipated the strategy of real business cycle models (Prescott 1986b; Plosser 1989). It is only in a footnote that Rodolfo Manuelli $(1986,3)$ notices that the model was the first to use stochastic shocks in the production function. In private correspondence with one of the authors, Brock argued for a very open modeling strategy. According to his view, the way forward should be based on an experimental recipe starting with Frank Ramsey and adding stochastic shocks for uncertainty (as in Brock and Mirman 1972), disutility of labor in the production function, money, sticky price vectors, and eventually some market failures. This unorthodox outlook on orthodoxy may explain why Brock and Mirman were denied progeny of real business cycle modeling.

8. A 1980 paper had speculated on the introduction of preference shocks alongside productivity ones, but the new version collapsed the former (Kydland and Prescott 1980).

9. There were four potential sources of persistence in the Kydland-Prescott model: autocorrelation of the exogenous technological shocks, time-dependent individual preferences, inventories as factors of production, and the "time-to-build" production function. K. Geert Rouwenhorst (1991) has argued that the "time-to-build" production function is insufficient to produce the cyclical behavior; for this the autocorrelation of exogenous shocks is required. 
John Long and Charles Plosser (1983) gave the new class of models the label of "Real Business cycles."10 Following work by Charles Nelson and Plosser (1982), they proposed a Cobb-Douglas production function with a single stochastic component, undermining the notion of a deterministic trend and replacing it by a nonstationary stochastic process with no tendency to return to a deterministic path. ${ }^{11}$ The Long and Plosser model relaxed the assumption of the autocorrelation of shocks. Defining an inputoutput structure they examined the propagation of a shock and an individual's smoothing of windfall capital gains. They later realized that serial correlation was critical to produce fluctuations (King, Plosser, and Rebelo 1988). It is significant that the Long and Plosser piece was never as influential as the Kydland and Prescott model. Although the authors simulated the time paths of their model economy to reveal cycle-like movements, this result did not seek to match the economic record. The model was illustrative but unpersuasive in the new classical sense of providing an "imitation" of the real economy.

The real business cycle models developed from Lucas's program. ${ }^{12}$ They assumed calibration in the place of econometric estimation, Kydland and Prescott (1982) comparing the time paths of their simulations with quarterly data for the U.S. postwar economy. ${ }^{13}$ Puzzle solving was focused on tweaking the models' specifications to replicate the autocorrelation and comovements in U.S. time-series data. ${ }^{14}$ The sources of fluctuations were not misperceptions but objective changes in the aggregate productivity function. The dynamic stochastic behavior of the model-worlds

10. Long and Plosser cite the working-paper version of Kydland and Prescott 1982, but their paper did not originate as a refinement of that model. In a personal communication of January 2008 to the authors, Plosser recalled that their paper was well underway before they saw the Kydland-Prescott one, adding, "We were intentionally trying to build a real model of fluctuations using growth theory. I think KP backed into that conclusion. Thus it is fair to say the papers were developed independently at about the same time."

11. The stochastic trend approach was further developed by James Stock and Mark Watson (1988a, 1988b), who hypothesize that variations in trends are responsible for an important part of the fluctuation of output in U.S. series. So did Stephen Beveridge and Nelson (1981) and Nelson and Plosser (1982), stating that business cycles can be defined as adjustments to changes in the growth paths.

12. Besides the intellectual kinship there is also a social connect. Lucas and Prescott met at Carnegie Mellon in the late 1960s and continued to collaborate for over two decades, well into Prescott's real business cycle years (Lucas and Prescott 1971, 1974; Prescott and Lucas 1972; Stokey, Lucas, and Prescott 1989). Arjo Klamer's (1984, 32-33) interview with Lucas captures this bond of friendship.

13. The calibration approach is not the only one available to the new classicals; see Cooley 1997. For an opposing view on the promise of calibration, see Hoover 1995.

14. For sympathetic surveys, see King and Rebelo 1999 and Rebelo 2005. 
emerged out of microeconomic principles of maximization and out of a situation in which all markets are permanently cleared.

Lucas (1987, 46-47) was supportive of the new generation, in 1987 calling Kydland and Prescott's work the "current frontier in business cycle research" and adding that they offer "a formulation that combines intelligible general equilibrium theory with an operational, empirical seriousness. . . I would like to call this progress." ${ }^{15}$ Lucas was critical to the extent that the "model focuses exclusively on real (as opposed to monetary) neoclassical considerations, which I think is a mistake."16

By locating the emergence of real business cycle models in the context of new classical macroeconomics, we aim to show its genetic distance from growth theory. Solow 1957 was not mentioned in the two seminal pieces of real business cycle models (Kydland and Prescott 1982; Long and Plosser 1983). Solow was on record as quite dismissive of the new classical enterprise. In his presidential lecture to the American Economic Association, he portrayed the equilibrium outlook as unreasonable, saying it is "legitimate to wonder why the unemployed do not feel themselves to be engaged in voluntary intertemporal substitution, and why they queue up in such numbers when legitimate jobs of their usual kind are offered during a recession" (Solow 1980, 7).

Solow was not engaged by the enterprise, but that did not mean that his work was not influential. Although real business cycle models emerged from the new classical program, its adoption of the neoclassical production function borrowed from Solow. The goal was to integrate business cycle and growth, a prospect that Solow (1982) shared. Solow and the new classicals concurred that the "technology" component of the production function was its dynamic and independent element.

\section{The Black Box Challenged}

The notion of shock entered the discourse on the growing economy in the 1980s. Later in the decade, real business cycle theory's attempts to straddle growth and fluctuations became an item of controversy. ${ }^{17}$ Our aim in

15. Lucas's assessment is not surprising given the close kinship between his models and Kydland and Prescott's work. The propagation side of their models is very similar; it is in the impulse element that they differ. See Lucas 1977.

16. See also the updated but largely unchanged commentary in Lucas 2007.

17. Reviewing real business cycle theory, Victor Zarnowitz (1985) did not think much of Kydland and Prescott's work. 
this section is to highlight how the interpretation of the Solow residual became a crucial item of that debate.

The opening salvo of the controversy was fired by Prescott at a CarnegieRochester Conference on Public Policy in 1985, with an essay titled "Theory Ahead of Business Cycle Measurement" (Prescott 1986b), in which he offered an updated version of his 1982 model with Kydland. While Kydland and Prescott (1982) had studied variance and correlation for the output of different sectors of the economy, the new empirical target was to simulate the dynamics for the American economy post-Korean War for such aggregate variables as investment, inventory stock, capital stock, consumption, hours of work, productivity, and real interest rate. Prescott judged a satisfactory match between his simulation and the record, but he found discrepancies in labor's sensitivity to changes in output, the recorded elasticity being well below the model's solution. Prescott considered the mismatch to be due to empirical measurement lagging behind theory development. ${ }^{18}$

Contemporaneously, at a National Bureau of Economic Research (NBER) conference in March 1986 in Cambridge, Massachusetts, Martin Eichenbaum and Kenneth Singleton (1986) offered an assessment of monetary shocks (changes to M1) to explain variance of aggregate output. They concluded that monetary shocks had an insignificant causal power, which led them by default to endorse an explanation through real shocks. Real business cycle models were supplanting Lucas's money models. At this triumphant stage, Solow's work receives mention. Prescott (1986b) credited Solow and Trevor Swan as the originators of growth theory from which he claimed business cycle theory partly derived. But more salient than ancestor worship was Prescott's use of Solow's (1957) method to

18. It should interest the historian that Prescott had in mind a parallel between contemporary debates and the famous "measurement without theory controversy" between the Cowles Commission and the NBER. In a 1990 paper, where Kydland and Prescott examined the ancestry of their program-Mitchell, Frisch, Slutsky, and Lucas - they endorsed Tjalling Koopmans's (1947) critique of Burns and Mitchell 1946: a theory is needed before variables are selected. Yet, following Lucas's critique, they disagreed with Koopmans's use of structural systems of equations, considering that imposing such a straitjacket was a "grave disservice" (Kydland and Prescott 1990, 4). Prescott may have been primed toward the "measurement without theory" debates by the April 1985 Carnegie-Rochester conference where Salih Neftci gave a paper on the NBER's method of fluctuation analysis. The series editors read it as "the first serious reconsideration of Tjalling Koopmans's judgment, advanced more than 30 years ago, that the National Bureau methodology indulges in "measurement without theory", (Brunner and Meltzer 1986, 2). 
obtain a measurement of technology.$^{19}$ Prescott concluded that economic fluctuations were optimal responses to uncertainty. Policy should be devoted to the institutional study of technology and an increase of its rate of change, in effect a proposition that echoed Solow's 1970 lectures. The policy brief of 1980s business cycle theory was aligned with that of 1960 s neoclassical growth theory.

It was Lawrence Summers, speaking to the NBER Economic Fluctuations Group, who engaged with Prescott's overview (Summers 1986). Summers's list of objections sought to turn Prescott's paper on its head: "Theory was ahead of measurement" because theory had been constructed with unobservables that forever eluded definitive study. Not all of Summers's objections are of interest to our argument. The second objection, "Where are the shocks?" zoomed in on Prescott's interpretation of changes in total factor productivity as technological shocks albeit with a small measurement error. Summers asked for historical examples to assert the validity of this hypothesis and offered an alternative interpretation where changes in the Solow residual reflected businesses hoarding labor in response to economic downturns.

Both Prescott's and Summers's articles were published as a debate in the Quarterly Review of the Federal Reserve Bank of Minneapolis, and Prescott (1986a) was given the chance to reply to Summers. To the charge that no technological shocks were discernable in the historical record, Prescott called on Eugen Slutsky's finding that "some stable low-order linear stochastic difference equations have been known to generate cycles. They do not have a few large shocks, they have small shocks, one every period." Stating that economists lacked a theory of technological change, Prescott called on Solow 1957 to argue that given the "finding that more than 75 percent of the changes in per capital output are accounted for by changes in the technology parameter, the evidence for variation in the rate of technological change is strong." Summers's argument of labor hoarding was classed as a measurement problem in the labor component of the production function, distinct from the measurement of technology. Solow's authoritative findings were at this point a rhetorical resource in defense of real business cycle models (Hartley 2006).

19. The following year, 1987, Solow was awarded the Nobel Prize for economics. Alongside a paper by R. C. O. Matthews reviewing the laureate's contributions, Prescott wrote in the Scandinavian Journal of Economics, restating his 1986 findings. He reasserted that he had "challenged the widely held view that variations in the Solow technological parameter are too small to account for a significant amount of business cycle fluctuations" (Prescott 1988, 10). 
The debate remained unsettled, since in 1989 the same arguments were repeated with a new cast of protagonists in the pages of the Journal of Economic Perspectives. Plosser was cast as defender of real business cycle theory. Mentioning Solow twice in his argument, Plosser refers to Solow 1957 as a piece of empirical research revealing that "changes in productivity and technology are the major factors determining economic growth." Further, "a crude but straightforward method [of obtaining some measure of the productivity shocks] is to follow the example provided by Solow" (Plosser 1989, 58).

Reprising Summers's criticisms, Gregory Mankiw reestimated the Solow residual to highlight substantial yearly variation. He clarified that "if the Solow residual is a valid measure of the change in the available production technology, then recessions are periods of technological regress" (Mankiw 1989, 84). Mankiw thus argued that for the 1982 recession there had been no reduction in the residual, contradicting the real business cycle argument. To counter the implausible interpretation, he proposed that cyclical changes in the Solow residual reflected firms' decisions to hold on to unnecessary and underutilized labor.

The interpretation of the Solow residual was center stage. ${ }^{20}$ What is striking is that the Solow residual remained stable to a degree, as an object. In figure 1 there are two representations of the Solow residual. The numerical values were the same for both authors and were not in dispute. It is their readings that differed. Plosser (panel A) framed the residuals alone and hence interpreted a fluctuating time series of irregular interval, suggestive of a random walk. Mankiw, on the other hand, provided a greater time range, a much more cluttered and erratic depiction. Critically, Mankiw plotted the residuals (panel B) against the income series to stake the claim that the residual was quite literally a leftover. It was not the residual that was controversial but what it meant, or, in Mankiw's terms, which was the "more appealing interpretation"?

The differing interpretations of the Solow residual were not alone in demarcating the two perspectives. Probably more significant was the New Keynesians' disbelief in the automatic full employment of the Walrasian real business cycle models. Further, the latter reserved a role for monetary

20. Our side-by-side report of this set of controversies highlights a striking, if habitual, divide in American economics. In effect, this was another installment of the "saltwater vs. freshwater" controversy. Mankiw $(1986,139)$ made it quite explicit: "Real business cycle theory is one of the currently 'hot' topics in macroeconomics, especially among those who live closer to lakes than to oceans." 
344 Tiago Mata and Francisco Louçã

A Figure 1

Annual Growth Rate of Technology

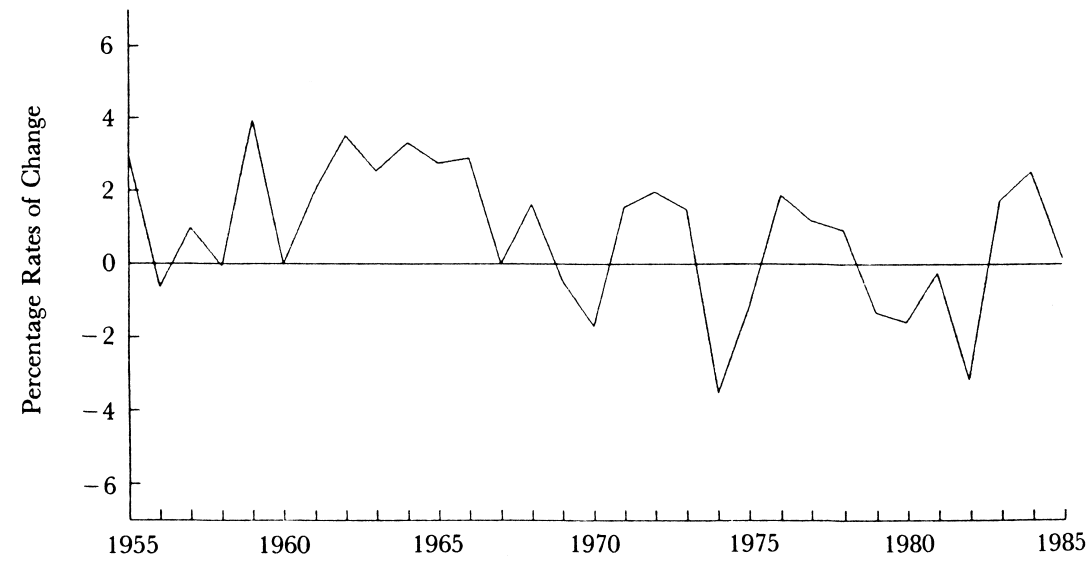

B Figure 1

Solow Residuals and Output Growth

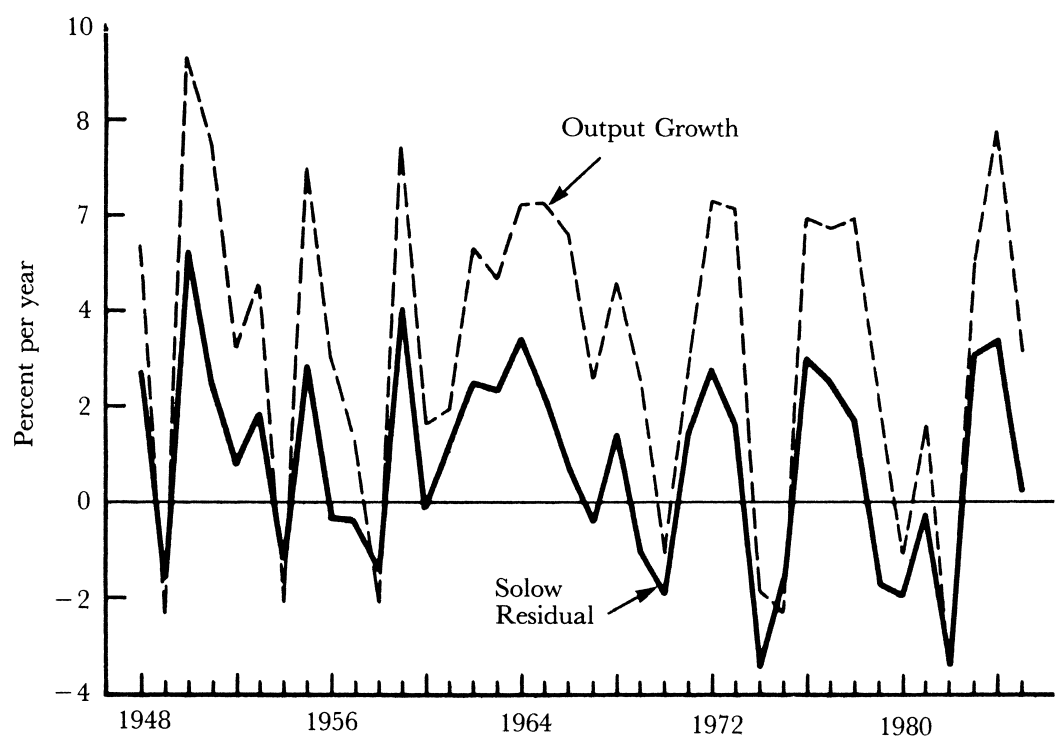

Figure 1 Plosser's (panel A) and Mankiw's (panel B) representations of the Solow residual. From Plosser 1989 and Mankiw 1989. 
policy that was seemingly forbidden by the "real" emphasis of their opponents' models. Ironically, the Solow residual was not what set them apart, but what they shared. It was a convenient subject of their discussion because it was an object that stood at the boundary between the two communities. ${ }^{21}$

\section{Opening the Box}

As the Solow residual became a focus of debate, it moved from being a rhetorical and symbolic object to become a research puzzle. It is in relation to the opening of this black box that we can envisage the landscape of models.

Contemporaneously to the business cycle debates, the subject of neoclassical growth theory witnessed a resurgence of interest. This was largely due to the work of two Chicago men: Paul Romer and Lucas. ${ }^{22}$ In the 1985 Marshall Lectures at Cambridge University, Lucas (1988) toyed with models of growth in which infinitely living families accumulated human capital. Further, human capital was formalized to have a spillover effect on the production function. Hence, while individual economic units faced constant returns to scale, the economy had increasing returns. Such work reinterpreted the Solow "technology" residual as disembodied human capital, a sediment of collective human capital. The more significant attack on growth theory was that of Romer (1986). He too sought to ban exogenous technological change from his competitive model. He specified a production function for technology production whose goods were in some measure nonexcludable, hence creating a positive externality. And although the production function of technology faced decreasing returns, output production had increasing returns.

The initial response of real business cycle theorists to the new classical versus New Keynesian controversy was tame. Real business cycle theorists met in June 1986 at the Portuguese Catholic University to discuss the state of their research program. ${ }^{23}$ Kydland and Prescott (1988) reconfigured their model to allow capital utilization to vary, hence separating the service of capital from its stock measurement. The volatility of their model

21. The notion of "boundary object" connecting scientific communities is well established in the social study of science (Star and Griesemer 1989).

22. For a history of events, characters, and the economics of Paul Romer, see Warsh 2006.

23. The papers were only published in 1988 and substantially updated with the latest literature. 
increased, although the nagging discrepancy between model and measured labor-output elasticity remained. Prescott $(1988,2006)$ never conceded to his critics that the real business cycle explanation required revision; he has consistently described the debate as settled to his advantage. In his Nobel lecture, Prescott dubbed his contribution part of a "revolution" that reunited macroeconomics with neoclassical economics. He took his 1986 findings that total factor productivity "shocks are the major contributor to fluctuations" to be "highly robust," lining up models akin to his as evidence (Prescott 2006, 11). Still, he was left to uncomfortably argue for the magic number of labor supply elasticity equals 3 . Definitive proof hung on that proposition. ${ }^{24}$

Despite statements otherwise, Prescott has struggled with explaining the Great Depression (De Vroey and Pensieroso 2006). Following Cole and Ohanian (1999), Prescott separates the 1929-33 from the post-1933 period. While changes in total factor productivity may partly account for the 1929-33 downswing, they are unable to account for the American economy's failure to return to trend growth. Prescott $(1999,26)$ considered that, "given the considerable evidence against technology, monetary, or banking explanations, I am led . . . to the view that there must have been a fundamental [New Deal] change in labor market institutions and industrial policies that lowered steady-state, or normal, market hours." This result has been heralded as a "novel fact" given by theoretical investigation (Kehoe and Prescott 2002), but it hides an inability of the real business cycle models to provide plausible explanations of the economic historical record.

Prescott also developed a telling interest in the work initiated by Lucas and Romer. With a former graduate student, Stephen Parente, Prescott began by establishing the "development facts" models ought to emulate (Parente and Prescott 1993). They then designed a model of national technology adoption from an ever-increasing stock of world technology (Parente and Prescott 1994). Differences in relative income shares between nations were explained by an unobservable "technological capital" parameter that was deemed embodied in the firm but invisible to the aggregate data. The authors introduced a term of "cost of technology adoption" that did most of the explanatory work. Looking at the data for Japan, they concluded that "Japan was converging to some balanced growth path and in

24. Prescott's reliance on the high elasticity of labor has informed his examination of why Americans' working hours differ so widely from European ones (Prescott 2004). This has sparked an independent controversy that rages on; see Faggio and Nickell 2007. 
1974 there was regime change, that is, a persistent and unanticipated change in the magnitude of the technology adoption barrier parameter" (Parente and Prescott 1994, 310). Hence the noisy flow of technology produced cycles, and it was the institutional interruption of its flow that set growth paths.

The Plosser branch of the real business cycle research program was more adventurous in rebuilding their models. To the 1986 conference, they restated their collapse of the trend-cycle distinction and with it the emergence of stochastic growth. They used the Lucas formulation to endogenize labor-augmenting technical progress. After Lucas's growth model had reinterpreted the "residual" as a social spillover from learning and human capital accumulation, one could hardly conceive of shocks originating out of this steady accumulation. Instead, the impulse was located in an equally mysterious and exogenous technology component in the production of human capital. It was a new black box within the old black box. Still, the move was not inconsequential. They found that "temporary disturbances to production possibilities ... have permanent effects on the levels of economic activity, because they permit temporary changes in the amount of resources allocated to growth. Thus, endogenous growth models generate integrated time series, even when the underlying shocks are stationary" (King, Plosser, and Rebelo 1988b, 325).

An idiosyncratic strategy in real business cycle models is to embrace the ambiguity of the Solow residual. In a recent paper, Costas Azariadis and Leo Kaas (2007) propose, in the spirit of Prescott's Nobel lecture, that dynamic general equilibrium is a "theory of everything." In their grand scheme the Solow residual becomes an index that "conveys information not just about the aggregate technology frontier but also how far inside that frontier the economy operates." It is said to depend on "sectoral productivities; on financial variables like debt-equity ratios, interest rates, and the distribution of equity positions, and on institutional variables like property rights of lenders" and hence wealth distribution (Azariadis and Kaas 2007, 38).

Summers's and Mankiw's interpretation of the Solow residual as permeable to labor hoarding, and hence a poor measure of technological change, was substantively restated by Robert Hall $(1986,1990) .{ }^{25}$ Hall argued that

25. The new classical response to Hall was given by Matthew Shapiro (1987), comparing output and factor price measures of productivity. He interpreted the null result of no differences between the two as proof that variation in output productivity (Solow residual) was not explained by changes to demand. 
yearly movements in the Solow residual may potentially reflect market power, increasing returns, external technical complementarities, chronic excess capacity, unmeasured variations in work effort and hours, errors in measuring capital or output, and monopsony power in the labor market. He then added that the residual would not be sensitive to overhead labor or labor hoarding, wage smoothing, adjustment costs, or price rigidities. ${ }^{26}$

The New Keynesian models of the cycle have distinguished themselves for an emphasis on time and sector rigidities in the determination of wage contracts, prices, and investment plans (see Mankiw and Romer 1991). There is no class of New Keynesian growth models, but a strand in endogenous growth models bears some kinship. ${ }^{27}$ Peter Howitt (1986) has interpreted the core of Keynes's message as revealing the prevalence of intertemporal coordination problems. Philippe Aghion and Howitt's research has sought to wire the New Keynesian adjustment processes with Schumpeterian insights for a study of long-run growth (Howitt 1994). This they accomplished in two papers in the early 1990s, one focusing explicitly on the concerns of the growth debate, the other on matters of unemployment (Aghion and Howitt 1992, 1994). Their highlight is that technology is disruptive: it renders old capital obsolete, leading to a destruction of jobs. Unemployment is "job search," as the adjustment process endemic to a changing economy. The connection between this proposal and the subject of the Solow residual and growth accounting was recently made explicit. Aghion and Howitt (2007) offer a hybrid neoclassical model with endogenous growth. The innovation dynamic is restated as an uncertain investment that is a function of the capital stock. The relationships between the factors and technology become more deeply entangled.

\section{Conclusion}

On the history of models that bring growth and fluctuation into a single frame, we have focused on the uses and meanings of a particularly prominent object: the Solow residual. The significance of Solow's 1957 work arose

26. James Hartley (2000) offers a microfoundations model that excludes the possibility of an aggregate production function. Under these conditions changes in technology will not register in the Solow residual.

27. This occurs despite the all-pervasive discredit of the trend-cum-cycle distinction. Following Nelson and Plosser 1982, Campbell and Mankiw (1987) have found that "innovations" were highly persistent in both U.S. quarterly postwar data and annual data from 1896 to 1984 . Research by Shapiro and Mark Watson (1988) and King et al. (1991) have studied the contribution of changes in productivity to U.S. income data modeled as a stochastic trend: the first found its impact to be about one-third, the latter found it to be roughly two-fifths. 
from having stabilized a method and result, the residual as reproducible object, a black box. This object was shown to traffic liberally across doctrinal divides in economics. Once on offer, the black box had a life of its own. Its relation to the original context and to the intentions and beliefs of its originator was severed. So while Denison used the residual in ways that were surely faithful to Solow, the new classicals employed it in ways that seemed counter to Solow's outlook. While the residual had always remained a problematic result in growth accounting, its borrowing by real business cycle theorists sought to establish it as a definitive representation of technology. Furthermore, in these models it was a short-run and stochastic technology, a novel and surprising interpretation.

As the claims of the new classicals came under scrutiny, so did the status and meaning of the object residual. The challenge by New Keynesians brought attention to it. The integration of growth and cycle has been shaped by the opening of this black box. Prescott has remained committed to his earlier interpretation of the Solow residual as stochastic technology. Others have sought to blanket a variety of supply shocks under the cover of the residual, abandoning attempts to decompose it. For the New Keynesians the "residual" was more evidence of market power and the need to integrate rigidities into the study of the cycle.

Solow $(2007,12)$ has consistently maintained the importance of the cycle in the modeling of growth, stating his worry "about the tendency of modern (American) macroeconomists to forget about the pathology of business cycles." But in a review of the recent growth literature he does not mention the models that market themselves as integrating growth and cycle (Solow 1994). His judgment on real business cycles has remained unappreciative. Writing for the prominent humanities journal Daedalus, Solow $(1997,52)$ casts real business cycle models with a minor role in the history of profession: "The bulk of the intellectual effort goes into the ways of showing that the data of observed fluctuations are compatible with the demands of the model. This is not easy because the key driving forcesirregular changes in tastes and technology—are not directly observable." However, his closing summary is intriguing, stating that "the more adventuresome advocates of Real Business Cycle Theory have found it necessary to modify many of the clean but extreme assumptions that give formal general equilibrium theory its artificial vanilla flavor. ... it has come closer and closer to the more or less 'Keynesian' model it was supposed to discredit" (52-53). These more interesting developments are in our narrative the puzzling through the Solow residual and its continued privileged role in the construction of comprehensive models of economic dynamics. 


\section{References}

Aghion, Philippe, and Peter Howitt. 1992. A Model of Growth through Creative Destruction. Econometrica 60.2:323-51.

- 1994. Growth and Unemployment. Review of Economic Studies 61.3:477-94.

- 2007. Capital, Innovation, and Growth Accounting. Oxford Review of Economic Policy 23.1:79-93.

Azariadis, Costas, and Leo Kaas. 2007. Is Dynamic General Equilibrium a Theory of Everything? Economic Theory 32.1:13-41.

Begg, David K. H. 1982. The Rational Expectations Revolution in Macroeconomics: Theories and Evidence. Baltimore, Md.: Johns Hopkins University Press.

Beveridge, Stephen, and Charles R. Nelson. 1981. A New Approach to Decomposition of Economic Time Series into Permanent and Transitory Components with Particular Attention to Measurement of the "Business Cycle." Journal of Monetary Economics 7.2:151-74.

Blaug, Mark. 1980. The Methodology of Economics: or, How Economists Explain. Cambridge: Cambridge University Press.

Brock, William A., and Leonard J. Mirman. 1972. Optimal Economic Growth and Uncertainty: The Discounted Case. Journal of Economic Theory 4:479-513.

Brunner, Karl, and Allan H. Meltzer. 1986. The National Bureau Method: International Capital Mobility and Other Essays. Amsterdam: North-Holland.

Burmeister, Edwin, and Rodney Dobell. 1970. Mathematical Theories of Economic Growth. [New York]: Macmillan.

Campbell, John Y., and N. Gregory Mankiw. 1987. Are Output Fluctuations Transitory? Quarterly Journal of Economics 102.4:857-80.

Cole, H. L., and L. E. Ohanian. 1999. The Great Depression in the United States from a Neoclassical Perspective. Federal Reserve Bank of Minneapolis Quarterly Review 23.1:2-24.

Cooley, T. F. 1997. Calibrated Models. Oxford Review of Economic Policy 13.3:55-69.

De Vroey, Michel, and Luca Pensieroso. 2006. Real Business Cycle Theory and the Great Depression: The Abandonment of the Abstentionist Viewpoint. Contributions to Macroeconomics 6.1. www.bepress.com/bejm/contributions/vol6/iss1/ art13.

Denison, Edward Fulton. 1962. The Sources of Economic Growth in the United States and the Alternatives before Us. [New York]: Committee for Economic Development.

- 1979. Accounting for Slower Economic Growth: The United States in the 1970's. Washington, D.C.: Brookings Institution.

— 1985. Trends in American Economic Growth, 1929-1982. Washington, D.C.: Brookings Institution.

Denison, Edward Fulton, and Brookings Institution. 1967. Why Growth Rates Differ: Postwar Experience in Nine Western Countries. Washington, D.C.: Brookings Institution.

— 1974. Accounting for United States Economic Growth, 1929-1969. Washington, D.C.: Brookings Institution. 
Dore, Mohammed H. I. 1993. The Macrodynamics of Business Cycles: A Comparative Evaluation. Cambridge, Mass.: Blackwell.

Eichenbaum, Martin, and Kenneth J. Singleton. 1986. Do Equilibrium Real Business Cycle Theories Explain Postwar U.S. Business Cycles? NBER Macroeconomics Annual 1:91-135.

Faggio, Giulia, and Stephen Nickell. 2007. Patterns of Work across the OECD. Economic Journal 117.521:F416-F440.

Freeman, Christopher. 1988. Introduction. In Technical Change and Economic Theory, edited by G. Dosi, C. Freeman, R. Nelson, G. Silverberg, and L. Soete. London: Pinter Publishers.

Hahn, F. H., and R. C. O. Matthews. 1964. The Theory of Economic Growth: A Survey. Economic Journal 74.296:779-902.

Hall, Robert E. 1986. Market Structure and Macroeconomic Fluctuations. Brookings Papers on Economic Activity 2:265-338.

- 1990. Invariance Properties of Solow's Productivity Residual. In Growth/ Productivity/Unemployment: Essays to Celebrate Bob Solow's Birthday, edited by P. Diamond. Cambridge: MIT Press.

Hartley, James. 2006. Kydland and Prescott's Nobel Prize: The Methodology of Time Consistency and Real Business Cycle Models. Review of Political Economy 18:1-28.

Hartley, James E. 2000. Does the Solow Residual Actually Measure Changes in Technology? Review of Political Economy 12.1:27-44.

Hoover, Kevin D. 1988. The New Classical Macroeconomics: A Sceptical Inquiry. Oxford: Blackwell.

- 1995. Facts and Artifacts: Calibration and the Empirical Assessment of Real Business Cycle Models. Oxford Economic Papers 47.1:24-44.

Howitt, Peter. 1986. The Keynesian Recovery. Canadian Journal of Economics/ Revue canadienne d'économique 19.4:626-41.

- 1994. Adjusting to Technological Change. Canadian Journal of Economics/ Revue canadienne d'économique 27.4:763-75.

Kantor, Brian. 1979. Rational Expectations and Economic Thought. Journal of Economic Literature 17.4:1422-41.

Kehoe, Timothy J., and Edward C. Prescott. 2002. Great Depressions of the Twentieth Century. Review of Economic Dynamics 5:1-18.

Kim, E. Han, Adair Morse, and Luigi Zingales. 2006. What Has Mattered to Economics since 1970. Journal of Economic Perspectives 20:189-202.

Kim, Kyun. 1988. Equilibrium Business Cycle Theory in Historical Perspective. Cambridge: Cambridge University Press.

King, R. G., and Sergio Rebelo. 1999. Resuscitating Real Business Cycles. In Handbook of Macroeconomics, edited by J. B. Taylor and M. Woodford. Amsterdam: North-Holland.

King, Robert G., Charles I. Plosser, and Sergio T. Rebelo. 1988a. Production, Growth, and Business Cycles: I. The Basic Neoclassical Model. Journal of Monetary Economics 21.2-3:195-232. 
- 1988b. Production, Growth, and Business Cycles: II. New Directions. Journal of Monetary Economics 21.2-3:309-41.

King, Robert G., Charles I. Plosser, James H. Stock, and Mark W. Watson. 1991. Stochastic Trends and Economic Fluctuations. American Economic Review 81.4:819-40.

Klamer, Arjo. 1984. Conversations with Economists: New Classical Economists and Opponents Speak Out on the Current Controversy in Macroeconomics. Totowa, N.J.: Rowman and Allanheld.

Koopmans, Tjalling C. 1947. Measurement without Theory. Review of Economic Statistics 29.3:161-72.

Kydland, Finn E., and Edward C. Prescott. 1980. Dynamic Optimal Taxation, Rational Expectations, and Optimal Control. Journal of Economic Dynamics and Control 2:79-91.

- 1982. Time to Build and Aggregate Fluctuations. Econometrica 50.6:1345-70.

. 1988. The Workweek of Capital and Its Cyclical Implications. Journal of Monetary Economics 21.2-3:343-60.

- 1990. Business Cycles: Real Facts and a Monetary Myth. Federal Reserve Bank of Minneapolis Quarterly Review 14.2:1-17.

Laidler, D. 1981. Monetarism: An Interpretation and an Assessment. Economic Journal 91.361:1-28.

Latour, Bruno. 1987. Science in Action: How to Follow Scientists and Engineers through Society. Cambridge: Harvard University Press.

Latour, Bruno, and Steve Woolgar. 1979. Laboratory Life: The Social Construction of Scientific Facts. Beverly Hills, Calif.: Sage.

Long, John B., Jr., and Charles I. Plosser. 1983. Real Business Cycles. Journal of Political Economy 91.1:39-69.

Louçã, Francisco. 2004. Swinging All the Way: The Education of Doctor Lucas and Foes. HOPE 36.4:689-734.

Lucas, Robert E., Jr. 1972. Expectations and the Neutrality of Money. Journal of Economic Theory 4.2:103-24.

- 1975. An Equilibrium Model of the Business Cycle. Journal of Political Economy 83.6:1113-44.

- 1977. Understanding Business Cycles. Carnegie-Rochester Conference Series on Public Policy 5:7-29.

- 1980. Methods and Problems in Business Cycle Theory. Journal of Money, Credit, and Banking 12.4:696-715.

- 1987. Models of Business Cycles. Oxford: Blackwell.

- 1988. On the Mechanics of Economic Development. Journal of Monetary Economics 22.1:3-42.

- 2004. Keynote Address to the 2003 HOPE Conference: My Keynesian Education. In The IS-LM Model: Its Rise, Fall, and Strange Persistence, edited by Michel De Vroey and Kevin D. Hoover. HOPE 36 (supplement): 12-24.

- 2007. Remarks on the Influence of Edward Prescott. Economic Theory 32.1:7-11. 
Lucas, Robert E., Jr., and Edward C. Prescott. 1971. Investment under Uncertainty. Econometrica 39.5:659-81.

- 1974. Equilibrium Search and Unemployment. Journal of Economic Theory 7.2:188-209.

Lucas, Robert E., Jr., and Thomas Sargent. 1979. After Keynesian Macroeconomics. Quarterly Review 3.2:1-17.

Mankiw, N. Gregory. 1986. Comment. Macroeconomics Annual 1:139-46.

1989. Real Business Cycles: A New Keynesian Perspective. Journal of Economic Perspectives 3.3:79-90.

Mankiw, N. Gregory, and David Romer. 1991. New Keynesian Economics. 2 vols. Cambridge: MIT Press.

Manuelli, Rodolfo E. 1986. Modern Business Cycle Analysis: A Guide to the Prescott-Summers Debate. Federal Reserve Bank of Minneapolis Quarterly Review 10.4:1-6.

Nelson, Charles R., and Charles R. Plosser. 1982. Trends and Random Walks in Macroeconomic Time Series: Some Evidence and Implications. Journal of Monetary Economics 10.2:139-62.

Ohanian, Harold L., and Lee E. Cole. 1999. The Great Depression in the United States from a Neoclassical Perspective. Federal Reserve Bank of Minneapolis Quarterly Review 23.1:2-24.

Parente, Stephen, and Edward C. Prescott. 1993. Changes in the Wealth of Nations. Federal Reserve Bank of Minneapolis Quarterly Review 17.2:3-16.

- 1994. Barriers to Technology Adoption and Development. Journal of Political Economy 102.2:298-321.

Plosser, Charles I. 1989. Understanding Real Business Cycles. Journal of Economic Perspectives 3.3:51-77.

Prescott, Edward C. 1986a. Response to a Skeptic. Federal Reserve Bank of Minneapolis Quarterly Review 10.4:27-33.

- 1986b. Theory Ahead of Business Cycle Measurement. Federal Reserve Bank of Minneapolis Quarterly Review 10.4:7-21.

- 1988. Robert M. Solow's Neoclassical Growth Model: An Influential Contribution to Economics. Scandinavian Journal of Economics 90.1:7-12.

- 1999. Observations on the Great Depression. Federal Reserve Bank of Minneapolis Quarterly Review 23.1:25-31.

—. 2004. Why Do Americans Work So Much More Than Europeans? Federal Reserve Bank of Minneapolis Quarterly Review 28.1:2-13.

- 2006. The Transformation of Macroeconomic Policy and Research. American Economist 50.1:3-20.

Prescott, Edward C., and Robert E. Lucas Jr. 1972. A Note on Price Systems in Infinite Dimensional Space. International Economic Review 13.2:416-22.

Rebelo, Sergio. 2005. Real Business Cycle Models: Past, Present, and Future. Scandinavian Journal of Economics 107.2:217-38.

Romer, Paul M. 1986. Increasing Returns and Long-Run Growth. Journal of Political Economy 94.5:1002-37. 
Rosenberg, Nathan. 1982. Inside the Black Box: Technology and Economics. Cambridge: Cambridge University Press.

Rouwenhorst, K. Geert. 1991. Time to Build and Aggregate Fluctuations: A Reconsideration. Journal of Monetary Economics 27.2:241-54.

Sent, Esther-Mirjam. 1998. The Evolving Rationality of Rational Expectations: An Assessment of Thomas Sargent's Achievements. Cambridge: Cambridge University Press.

Shapiro, Matthew D. 1987. Are Cyclical Fluctuations in Productivity Due More to Supply Shocks or Demand Shocks? American Economic Review 77.2:118-24.

Shapiro, Matthew D., and Mark W. Watson. 1988. Sources of Business Cycle Fluctuations. NBER Macroeconomics Annual 3:111-48.

Sheffrin, Steven M. 1983. Rational Expectations. Cambridge: Cambridge University Press.

Solow, Robert M. 1956. A Contribution to the Theory of Economic Growth. Quarterly Journal of Economics 70.1:65-94.

- 1957. Technical Change and the Aggregate Production Function. Review of Economics and Statistics 39.3:312-20.

-1963. Capital Theory and the Rate of Return. Amsterdam: North-Holland.

- 1970. Growth Theory: An Exposition. New York: Oxford University Press.

- 1980. On Theories of Unemployment. American Economic Review 70.1:1-11.

- 1982. Some Lessons from Growth Theory. In Financial Economics: Essays in Honor of Paul Cootner, edited by P. H. Cootner, W. F. Sharpe, and C. M. Cootner. Englewood Cliffs, N.J.: Prentice-Hall.

- 1984. Letter to Frank Hahn, January 12. Robert Solow Papers, box 15. Rare Book, Manuscript, and Special Collections Library, Duke University.

- 1985. Economic History and Economics. American Economic Review 75.2:328-31.

- 1994. Perspectives on Growth Theory. Journal of Economic Perspectives 8.1:45-54.

- 1997. How Did Economics Get That Way and What Way Did It Get? Daedalus 126.1:39-58.

- 2007. The Last 50 Years in Growth Theory and the Next 10. Oxford Review of Economic Policy 23.1:3-14.

Star, Susan Leigh, and James R. Griesemer. 1989. Institutional Ecology, "Translations," and Boundary Objects: Amateurs and Professionals in Berkeley's Museum of Vertebrate Zoology, 1907-39. Social Studies of Science 19.3:387-420.

Stock, James H., and Mark W. Watson. 1988a. Testing for Common Trends. Journal of the American Statistical Association 83.404:1097-107.

- 1988b. Variable Trends in Economic Times Series. Journal of Economic Perspectives 2.3:147-74.

Stokey, Nancy L., Robert Lucas, and Edward C. Prescott. 1989. Recursive Methods in Economic Dynamics. Cambridge: Harvard University Press.

Summers, Lawrence. 1986. Some Skeptical Observations on Real Business Cycle Theory. Federal Reserve Bank of Minneapolis Quarterly Review 10.4:22-26. 
Tobin, James. 1981. The Monetarist Counter-Revolution Today-an Appraisal. Economic Journal 91.361:29-42.

Walters, A. A. 1963. Production and Cost Functions: An Econometric Survey. Econometrica 31.1-2:1-66.

Warsh, David. 2006. Knowledge and the Wealth of Nations: A Story of Economic Discovery. London: Norton.

Weintraub, E. Roy. 1991. Stabilizing Dynamics: Constructing Economic Knowledge. Cambridge: Cambridge University Press.

Yonay, Yuval P. 1994. When Black Boxes Clash: Competing Ideas of What Science Is in Economics, 1924-39. Social Studies of Science 24.1:39-80.

Zarnowitz, Victor. 1985. Recent Work on Business Cycles in Historical Perspective: A Review of Theories and Evidence. Journal of Economic Literature 23.2:523-80. 